\title{
IMPLEMENTATION OF THE SAW METHOD AS A DECISION SUPPORT FOR GIVING FEASIBILITY OF KUR ON BANK MANDIRI DRAMAGA BOGOR
}

\author{
Frieyadie1; Riki Setiyawan $^{2(*)}$ \\ Information Systems \\ STMIK Nusa Mandiri, Jakarta, Indonesia \\ www.nusamandiri.ac.id \\ 1 frieyadie@nusamandiri.ac.id; ${ }^{2}$ rikisetiyawan12@gmail.com \\ ${ }^{*}$ Corresponding Author
}

\begin{abstract}
Currently, the public's interest is very high to get KUR, but it makes it difficult for banks to determine who is eligible to receive the KUR and in the process of giving credit using the "LOS" system but this system is still quite a time consuming to analyze customer data and the process requires consideration and good analysis from the leader, due to the high number of problem loans. The SAW method used in this study. The SAW method is able to simplify and accelerate the results of credit lending recommendations. The calculation results obtained by debtors who are very worthy given credit as much as 1 debtor (4\%), decent debtors with low risk as many as 16 debtors (70\%), and worthy of being given with high risk as much as 6 debtors (26\%) The purpose of this study to know the process and requirements for granting business credit at Bank Mandiri Dramaga Bogor.
\end{abstract}

Keywords: KUR, Kredit Usaha Rakyat, SAW Method

Abstrak - Saat ini minat masyarakat sangat tinggi untuk mendapatkan KUR, Namun membuat pihak bank kesulitan dalam menetukan siapakah yang layak menerima KUR tersebut dan pada proses pemberian kredit sudah menggunakan Sistem "LOS" namaun sistem ini masih cukup memakan waktu untuk dianalisa data nasabah dan prosesnya membutuhkan pertimbangan dan analisa yang baik dari pemimpin, dikarnakan tingginya angka kredit bermasalah. Metode SAW yang digunakan pada penelitian ini. Metode SAW ini mampu mempermudah dan mempercepat hasil rekomentasi pemberian kredit. Hasil perhitungan yang didapat oleh debitur yang sangat layak diberikan kredit sebanyak 1 debitur (4\%), debitur yang layak dengan risiko rendah sebanyak 16 debitur (70\%), dan layak diberikan dengan risiko tinggi sebanyak 6 debitur (26\%) Tujuan penelitian ini untuk mengetahui proses dan syarat pemberian kredit usaha rakyat di Bank Mandiri Dramaga Bogor.
Kata Kunci: KUR, Kredit Usaha Rakyat, SAW Method

\section{INTRODUCTION}

Kredit Usaha Rakyat (KUR) is a government program that aims to develop or increase viable microbusinesses, increase the competitiveness capacity of MSMEs, encourage economic growth and employment absorption, and reduce poverty. Bank Mandiri, Dramaga Bogor Branch, is one of the most reliable banks in Bogor, which is trusted by the government to provide credit to prospective customers.

Currently, the public's interest is very high to get KUR, but it makes it difficult for banks to determine who is eligible to receive the KUR (R. Febrianti et al., 2018) (Zein, 2014) (Riyandi et al., 2017) and in the process of granting credit already using the system "LOS" but this system is still quite a time consuming to analyze customer data. And the process requires good judgment and analysis from the leader, due to the high number of problem loans (Riyandi et al., 2017) (Riyandi et al., 2017), (Yasdomi \& Chandra, 2017)(Kanuru et al., 2018)(Waspodo et al., 2014)(M. Chandra C. Utomo, Wayan Firdaus Mahmudy, 2014) to avoid the possibility of losses to be suffered by banks due to customers who do not fulfill their obligations according to the agreement. Many factors must be considered when making decisions in granting credit strongly influenced by the provisions and policies of the leaders of the Bank Mandiri Branch Dramaga Bogor

In the credit rating process or often also referred to as credit analysis conducted by credit analysis between one official and another credit officer has a different opinion on the request so that credit analysts sometimes have difficulty and require a long time in determining the number of loans to be given to customers based on teaching process The selection process for loan disbursement at PT Bank Mandiri, Dramaga 
Branch, Bogor, now the customer has to fill in the form that has been given and starts from the initial selection process to check the suitability of data from prospective customers which includes personal data, business feasibility, income data, and the latest loan data collateral data. Then a check from both BI Checking and the customer's business location visit after a Credit analysis and ability to pay from the customer, then the team of analysts and the Bank's leadership can determine whether or not the customer gets a KUR loan. However, the credit granting system has caused the granting of credit to be subjective (Mulyati \& Dwiputri, 2018) and it is not appropriate in determining the granting of credit to customers (Sibyan, 2018).

Decision support with the Simple Additive Weighting (SAW) method (Utomo \& Ipmawati, 2016)(Hermawan \& Evan, 2019) with the basic concept of finding a weighted sum of the performance ratings on each alternative on all criteria (Sudiarjo \& Ruuhwan, 2020), is expected to be able to facilitate and accelerate the process of granting credit that does not yet have a certain mathematical weighting value and calculation and can reduce credit problems. i.e. bad credit. The purpose of this study was to determine the process and conditions for people's business credit at Bank Mandiri Dramaga Bogor, to implement the Simple Additive Weighting (SAW) method in granting credit, and to facilitate the performance of banks in classifying members in debtors and providing effective service processes.

\section{MATERIALS AND METHODS}

1. Data Collection Methods

Data collection methods relate to how to collect data, who is the source, and what tools are used.

a. Observation, this activity does direct observation in Bank Mandiri Dramaga Bogor unit on the workflow that is carried out and recorded systematically and then studied so that it gets the materials needed.

b. Interview, this activity held a question and answer session with Mr. Nisan as the head of the Bank Mandiri Micro Dramaga unit in Bogor to get more specific material.

c. Literature study, this activity collects researcher data from various sources that already exist.

2. Research Population

Population research, this activity is collecting data at Bank Mandiri Dramaga Bogor unit by sampling. The population in this study were debtors who borrowed credit loans in 2019 Bank
Mandiri Dramaga. All items in the population have the same opportunity (probability) to be selected as sample items. The sampling technique that I use is simple random sampling. In determining the sample of the population the writer uses the Slovin formula:

$\mathrm{n}=\frac{\mathrm{N}}{1+\mathrm{Ne}^{2}}$

Where: $\mathrm{n}=$ sample; $\mathrm{N}=$ Population; $\mathrm{e}=$ Estimated level of $10 \%$

Where the population of credit borrowers in March 2019 at Bank Mandiri Dramaga is 30 Debtors, with an estimated error rate of $10 \%$, thus the calculation of the sample according to the Slovin formula is as follows:

$\mathrm{n}=\frac{30}{1+30 \cdot(10 \%)^{2}}=23$

The required number of samples is 23 debtors at Bank Mandiri Dramaga in March 2019.

Table 1 Data of Bank Mandiri KUR Debtor Candidates for Dramaga Branch in the January March 2019 Period

\begin{tabular}{|c|c|c|}
\hline NO & No PK & Name \\
\hline 1 & XXXXXXXX555XX & TATANG MIHARJA \\
\hline 2 & XXXXXXXX393XX & ISHAK \\
\hline 3 & XXXXXXXX392XX & MUMUN \\
\hline 4 & XXXXXXXX250XX & MOCH. HASIM \\
\hline 5 & XXXXXXXX505XX & LUKMAN HAKIM \\
\hline \multirow[t]{2}{*}{6} & XXXXXXXX390XX & HERMAN \\
\hline & & MUHAMAD CECEP \\
\hline \multirow[t]{2}{*}{7} & XXXXXXXX230XX & SUPRIANA \\
\hline & & ARYATI \\
\hline 8 & XXXXXXXX225XX & SAPARTINAH \\
\hline 9 & XXXXXXXX225XX & SADI \\
\hline \multirow[t]{2}{*}{10} & XXXXXXXX347XX & DEDE RODIAH \\
\hline & & ALMAIDAH \\
\hline 11 & XXXXXXXX203XX & AGUSTIN \\
\hline 12 & XXXXXXXX342XX & KASMAN \\
\hline 13 & XXXXXXXX318XX & SITI NURYANTI \\
\hline 14 & XXXXXXXX158XX & TATANG \\
\hline 15 & XXXXXXXX157XX & WAHADI \\
\hline 16 & XXXXXXXX318XX & SITI KARIMAH \\
\hline 17 & XXXXXXXX317XX & EVA LASTRINA \\
\hline 18 & XXXXXXXX278XX & ANI \\
\hline 19 & XXXXXXXX135XX & RENA HIDAYAT \\
\hline 20 & XXXXXXXX261XX & SITI MARIYAM \\
\hline \multirow[t]{2}{*}{21} & XXXXXXXX417XX & LINDA DWIYANTI \\
\hline & & YUNIAR \\
\hline \multirow[t]{2}{*}{22} & XXXXXXXX439XX & ANGGRAENI \\
\hline & & MOHAMAD \\
\hline 23 & XXXXXXXX440XX & NAZMUDDIN \\
\hline
\end{tabular}

Source: (Bank Mandiri, 2019) 
1. Data Analysis Method

To achieve the research objectives, the analysis used is quantitative data analysis. Where quantitative data is data in the form of numbers. In accordance with its shape, quantitative data can be processed or analyzed using statistical calculation techniques (Siyoto \& Sodik, 2015). The analytical method used for decision support is Simple Additive Weighting (SAW) (Hasugian et al., 2018)

Determining the provision of credit to Bank Mandiri Dramaga Bogor is determined by using several criteria to facilitate data processing. In selecting the Mandiri Dramaga Bogor loan application, criteria, and weighting criteria are needed to do the calculation so that the best alternative will be obtained. The loan criteria that have been determined are as follows:

Table 2 Criteria Table

\begin{tabular}{cl}
\hline Criteria C & Description \\
\hline $\mathrm{C}_{1}$ & Character \\
$\mathrm{C}_{2}$ & Capital \\
$\mathrm{C}_{3}$ & Capasity \\
$\mathrm{C}_{4}$ & Collateral \\
$\mathrm{C}_{5}$ & Condition \\
\hline
\end{tabular}

Source: (Setiyawan \& Frieyadie, 2019)

Based on table 2 of these criteria, a level of importance of criteria is determined based on the predetermined weight value into fuzzy numbers. Matching rating of each alternative for each criterion is shown in Table 3 below:

Table 3 Fuzzy Numbers

\begin{tabular}{lc}
\hline \multicolumn{1}{c}{ Fuzzy Numbers } & Score \\
\hline Very Low (VL) & 1 \\
Low (L) & 2 \\
Enough (E) & 3 \\
Height (H) & 4 \\
Very High (VH) & 5 \\
\hline
\end{tabular}

Source: (Setiyawan \& Frieyadie, 2019)

Based on the criteria in Table 2 above the matching rating of each alternative (Ai) on each predetermined criterion $(\mathrm{Cj})$, then the translation of the weight of each criterion $(\mathrm{Cj})$ that has been converted to fuzzy numbers

\section{a. Character}

Character / Personality Research consists of data about the personality of the prospective customer such as personal traits, daily habits, ways of life, conditions, and family background as well as his liking. Character values can be seen in Table 4 below. If all indicators meet the requirements, they will get maximum points. Indicators assessed include a) Can be cooperative; b) Good economic conditions; c) Can keep the promise of how the assessment of local residents.

Table 4 Character Values

\begin{tabular}{cll}
\hline Criteria & Applicant Criteria & Crips Value \\
\hline \multirow{4}{*}{$\begin{array}{c}\text { Character } \\
\text { (Personality) }\end{array}$} & Very less & 1 \\
\cline { 2 - 3 } & Less & 2 \\
\cline { 2 - 3 } & Enough & 3 \\
\cline { 2 - 3 } & Good & 4 \\
\cline { 2 - 3 } & Very good & 5 \\
\hline
\end{tabular}

Source: (Setiyawan \& Frieyadie, 2019)

b. Capasity

The indicators used in determining loan recipients are based on capacity criteria, as in Table 5 below:

\begin{tabular}{clc}
\multicolumn{3}{c}{ Table 5 Capacity Criteria } \\
\hline \multirow{2}{*}{ Criteria } & \multicolumn{1}{c}{ Applicant Criteria } & $\begin{array}{c}\text { Crips } \\
\text { Value }\end{array}$ \\
\hline \multirow{3}{*}{$\begin{array}{c}\text { Capacity } \\
\text { (Length of } \\
\text { Effort) }\end{array}$} & Length of Effort $<$ 2 Tahun & 1 \\
\cline { 2 - 3 } & Length of Effort $>=$ 2 Tahun & 2 \\
\cline { 2 - 3 } & Length of Effort $>=3$ Tahun & 3 \\
\cline { 2 - 3 } & Length of Effort $>=4$ Tahun & 4 \\
\cline { 2 - 3 } & Length of Effort $>=5$ Tahun & 5 \\
\hline
\end{tabular}

Source: (Setiyawan \& Frieyadie, 2019)

c. Capital

The indicators used in determining loan recipients are based on capital categories, as in table 6 below:

Table 6 Capital Criteria

\begin{tabular}{|c|c|c|}
\hline Criteria & $\begin{array}{c}\text { Applicant } \\
\text { Criteria }\end{array}$ & $\begin{array}{l}\text { Crips } \\
\text { Value }\end{array}$ \\
\hline \multirow{5}{*}{$\begin{array}{c}\text { Capacity } \\
\text { (Amount of venture capital } \\
\text { other than loans) }\end{array}$} & $0 \%$ & 1 \\
\hline & $<=10 \%$ & 2 \\
\hline & $<=20 \%$ & 3 \\
\hline & $<=30 \%$ & 4 \\
\hline & $>30 \%$ & 5 \\
\hline
\end{tabular}

Source: (Setiyawan \& Frieyadie, 2019)

d. Collateral

The indicators used in determining loan recipients are based on collateral categories, as in Table 7 below:

Table 7 Collateral Criteria

\begin{tabular}{|c|c|c|}
\hline Criteria & Applicant Criteria & $\begin{array}{c}\text { Crips } \\
\text { Value }\end{array}$ \\
\hline \multirow{5}{*}{ 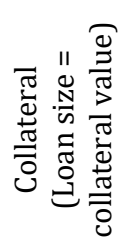 } & $>130 \%$ From the Guarantee Value & 1 \\
\hline & $>=110 \%$ From the Guarantee Value & 2 \\
\hline & $>=100 \%$ From the Guarantee Value & 3 \\
\hline & $>=80 \%$ From the Guarantee Value & 4 \\
\hline & $<80 \%$ From the Guarantee Value & 5 \\
\hline
\end{tabular}

Source: (Setiyawan \& Frieyadie, 2019) 
e. Condition

The indicators used in determining loan recipients based on the condition category are determined in the following table 8:

Table 8 Condition Criteria

\begin{tabular}{rlr}
\hline \multirow{2}{*}{ Criteria } & \multicolumn{1}{c}{ Applicant Criteria } & $\begin{array}{c}\text { Crips } \\
\text { Value }\end{array}$ \\
\hline \multirow{2}{*}{$:$} & Very influential & 1 \\
\cline { 2 - 3 } & Take effect & 2 \\
\cline { 2 - 3 } & Sometimes & 3 \\
\cline { 2 - 3 } & No effect & 4 \\
\cline { 2 - 3 } & Very no effect & 5 \\
\hline
\end{tabular}

Source: (Setiyawan \& Frieyadie, 2019)

The evaluation criteria conducted by Bank Mandiri Bogor were carried out with 5C. The criteria outlined above, the decision-maker gives a weight value (W), based on the level of importance of each criterion needed. The weight values of each criterion in table 9 are as follows:

Table 9 Importance of Criteria

\begin{tabular}{ccc}
\hline $\begin{array}{c}\text { Criteria } \\
\mathrm{C}\end{array}$ & Description & Weight \\
\hline $\mathrm{C}_{1}$ & Character & 35 \\
\hline
\end{tabular}

\begin{tabular}{lll}
\hline $\mathrm{C}_{2}$ & Capital & 15 \\
\hline $\mathrm{C}_{3}$ & Capasity & 25 \\
\hline $\mathrm{C}_{4}$ & Collateral & 15 \\
\hline $\mathrm{C}_{5}$ & Condition & 10 \\
\hline
\end{tabular}

Source: (Riyandi et al., 2017)

The parameter of the feasibility of prospective debtors at an independent bank can be seen in table 10 below.

Table 10 Feasibility Parameters

\begin{tabular}{ll}
\multicolumn{1}{c}{$\begin{array}{c}\text { Alternative } \\
\text { Values(Vi) }\end{array}$} & \multicolumn{1}{c}{ Description } \\
\hline$<=50$ & Not feasible \\
\hline $50-<=70$ & Worth the Big Risk \\
\hline $70-<=90$ & Worth the small risk \\
\hline $90-100$ & Very decent
\end{tabular}

Source: (Riyandi et al., 2017)

\section{RESULTS AND DISCUSSION}

Match Rating Value each alternative for each criterion is determined for a match rating for each alternative for each criterion specified above, in table 11 below:

Table 11 Alternative Match Ratings

\begin{tabular}{|c|c|c|c|c|c|}
\hline \multirow[b]{2}{*}{ Alternative (debtor) } & \multicolumn{5}{|c|}{ Criteria } \\
\hline & Character C1 & Capital C2 & Capasity C3 & Collateral C4 & Condition C5 \\
\hline A1 & 4 & 5 & 4 & 3 & 3 \\
\hline A2 & 4 & 4 & 2 & 5 & 4 \\
\hline A3 & 3 & 4 & 3 & 4 & 3 \\
\hline A4 & 4 & 3 & 4 & 3 & 4 \\
\hline A5 & 4 & 4 & 4 & 3 & 4 \\
\hline A6 & 4 & 4 & 3 & 3 & 5 \\
\hline A7 & 3 & 4 & 4 & 4 & 4 \\
\hline A8 & 4 & 3 & 5 & 3 & 3 \\
\hline A9 & 5 & 4 & 4 & 3 & 4 \\
\hline A10 & 4 & 3 & 4 & 5 & 4 \\
\hline A11 & 4 & 3 & 5 & 4 & 3 \\
\hline A12 & 2 & 3 & 4 & 3 & 4 \\
\hline A13 & 3 & 4 & 3 & 4 & 3 \\
\hline A14 & 4 & 3 & 4 & 5 & 3 \\
\hline A15 & 5 & 4 & 5 & 4 & 4 \\
\hline A16 & 4 & 5 & 4 & 3 & 5 \\
\hline A17 & 4 & 3 & 5 & 4 & 4 \\
\hline A18 & 3 & 3 & 3 & 4 & 3 \\
\hline A19 & 4 & 5 & 3 & 4 & 4 \\
\hline A20 & 2 & 3 & 4 & 3 & 5 \\
\hline A21 & 4 & 4 & 3 & 4 & 4 \\
\hline A22 & 3 & 3 & 4 & 5 & 3 \\
\hline A23 & 4 & 3 & 3 & 2 & 4 \\
\hline
\end{tabular}

Source: (Setiyawan \& Frieyadie, 2019)

\section{Decision Matrix}

After the alternative rating values for each criterion are determined, the next is to make a decision matrix $(\mathrm{X})$ formed from the match rating table of each alternative for each criterion. The $\mathrm{X}$ value of each alternative (Ai) for each 
predetermined criterion $(\mathrm{Cj})$, can be seen as figure 1 below.

$$
\left(\begin{array}{lllll}
4 & 5 & 4 & 3 & 3 \\
4 & 4 & 2 & 5 & 4 \\
3 & 4 & 3 & 4 & 3 \\
4 & 3 & 4 & 3 & 4 \\
4 & 4 & 4 & 3 & 4 \\
4 & 4 & 3 & 3 & 5 \\
3 & 4 & 4 & 4 & 4 \\
4 & 3 & 5 & 3 & 3 \\
5 & 4 & 4 & 3 & 4 \\
4 & 3 & 4 & 5 & 4 \\
4 & 3 & 5 & 4 & 3 \\
2 & 3 & 3 & 3 & 4 \\
3 & 4 & 3 & 4 & 3 \\
4 & 3 & 4 & 5 & 3 \\
5 & 4 & 5 & 4 & 4 \\
4 & 5 & 4 & 3 & 5 \\
4 & 3 & 5 & 4 & 4 \\
3 & 3 & 3 & 4 & 3 \\
4 & 5 & 3 & 4 & 4 \\
2 & 3 & 4 & 3 & 5 \\
4 & 4 & 3 & 4 & 4 \\
3 & 3 & 4 & 5 & 3 \\
4 & 3 & 3 & 2 & 4
\end{array}\right)
$$

Source: (Setiyawan \& Frieyadie, 2019)

Figure 1 Decision Matrix

\section{Decision Matrix Normalization (X)}

The process of normalizing the decision matrix (X) to a scale that can be compared with all existing alternative ratings (Purnama et al., 2019).

$R_{i j}=\frac{X_{i j}}{\operatorname{Max} X_{i j}}$

The results of matrix normalization (Rij) form a normalized matrix (R) as Figure 2 below.

$\left(\begin{array}{ccccc}0.8 & 1 & 0.8 & 0.6 & 0.6 \\ 0.8 & 0.8 & 0.4 & 1 & 0.8 \\ 0.6 & 0.8 & 0.6 & 0.8 & 0.6 \\ 0.8 & 0.6 & 0.8 & 0.6 & 0.8 \\ 0.8 & 0.8 & 0.8 & 0.6 & 0.8 \\ 0.8 & 0.8 & 0.6 & 0.6 & 1 \\ 0.6 & 0.8 & 0.8 & 0.8 & 0.8 \\ 0.8 & 0.6 & 1 & 0.6 & 0.6 \\ 1 & 0.8 & 0.8 & 0.6 & 0.8 \\ 0.8 & 0.6 & 0.8 & 1 & 0.8 \\ 0.8 & 0.6 & 1 & 0.8 & 0.6 \\ 0.4 & 0.6 & 0.6 & 0.6 & 0.8 \\ 0.6 & 0.8 & 0.6 & 0.8 & 0.6 \\ 0.8 & 0.6 & 0.8 & 1 & 0.6 \\ 1 & 0.8 & 1 & 0.8 & 0.8 \\ 0.8 & 1 & 0.8 & 0.6 & 1 \\ 0.8 & 0.6 & 1 & 0.8 & 0.8 \\ 0.6 & 0.6 & 0.6 & 0.8 & 0.6 \\ 0.8 & 1 & 0.6 & 0.8 & 0.8 \\ 0.4 & 0.6 & 0.8 & 0.6 & 1 \\ 0.8 & 0.8 & 0.6 & 0.8 & 0.8 \\ 0.6 & 0.6 & 0.8 & 1 & 0.6 \\ 0.8 & 0.6 & 0.6 & 0.4 & 0.8 \\ & & & & \\ 0.6 & & 0.8 & 0.8 & \end{array}\right)$

Source: (Setiyawan \& Frieyadie, 2019)
Figure 2 Normalized Matrix

\section{Preference Value (Vi)}

Next, calculate the final result of the preference value (Vi) obtained from the sum of the multiplications of normalized matrix row elements $(\mathrm{R})$ with preference weights $(\mathrm{W})$ corresponding to the matrix column elements (R). Preference Weight: $35,15,25,15,10$. Table 12 , test results where the initial value of students is processed using the SAW method and get the final result value in the calculation of preference values.

Table 12 Testing Results

\begin{tabular}{ccccccc}
\hline Alternative & \multicolumn{6}{c}{ Criteria } \\
\cline { 2 - 7 } (Debtor) & C1 & C2 & C3 & C4 & C5 & Total \\
\hline A1 & 28 & 15 & 20 & 9 & 6 & 78 \\
A2 & 28 & 12 & 10 & 15 & 8 & 73 \\
A3 & 21 & 12 & 15 & 12 & 6 & 66 \\
A4 & 28 & 9 & 20 & 9 & 8 & 74 \\
A5 & 28 & 12 & 20 & 9 & 8 & 77 \\
A6 & 28 & 12 & 15 & 9 & 10 & 74 \\
A7 & 21 & 12 & 20 & 12 & 8 & 73 \\
A8 & 28 & 9 & 25 & 9 & 6 & 77 \\
A9 & 35 & 12 & 20 & 9 & 8 & 84 \\
A10 & 28 & 9 & 20 & 15 & 8 & 80 \\
A11 & 28 & 9 & 25 & 12 & 6 & 80 \\
A12 & 14 & 9 & 15 & 9 & 8 & 55 \\
A13 & 21 & 12 & 15 & 12 & 6 & 66 \\
A14 & 28 & 9 & 20 & 15 & 6 & 78 \\
A15 & 35 & 12 & 25 & 12 & 8 & 92 \\
A16 & 28 & 15 & 20 & 9 & 10 & 82 \\
A17 & 28 & 9 & 25 & 12 & 8 & 82 \\
A18 & 21 & 9 & 15 & 12 & 6 & 63 \\
A19 & 28 & 15 & 15 & 12 & 8 & 78 \\
A20 & 14 & 9 & 20 & 9 & 10 & 62 \\
A21 & 28 & 12 & 15 & 12 & 8 & 75 \\
A22 & 21 & 9 & 20 & 15 & 6 & 71 \\
A23 & 28 & 9 & 15 & 6 & 8 & 66 \\
\hline Source: Setiyawan \& Frieyadie, 2019$)$ &
\end{tabular}

The results of the calculation of the value of preferences in each alternative prospective debtor, then to see who is the highest-ranking debtor, makes Table 13 a ranking table based on the final results of the ranking calculation from highest to lowest value, and will be explained in the following table:

Table 13 Ranking Results from Highest to Lowest Value

\begin{tabular}{ccc}
\hline Alternative Data & Total & Rank \\
\hline A15 & 92 & 1 \\
A9 & 84 & 2 \\
A16 & 82 & 3 \\
A17 & 82 & 4 \\
A10 & 80 & 5 \\
A11 & 80 & 6 \\
A1 & 78 & 7 \\
\hline
\end{tabular}




\begin{tabular}{ccc}
\hline Alternative Data & Total & Rank \\
\hline A14 & 78 & 8 \\
A19 & 78 & 9 \\
A5 & 77 & 10 \\
A8 & 77 & 11 \\
A21 & 75 & 12 \\
A4 & 74 & 13 \\
A6 & 74 & 14 \\
A2 & 73 & 15 \\
A7 & 73 & 16 \\
A22 & 71 & 17 \\
A3 & 66 & 18 \\
A13 & 66 & 19 \\
A23 & 66 & 20 \\
A18 & 63 & 21 \\
A20 & 62 & 22 \\
A12 & 55 & 23 \\
\hline
\end{tabular}

Source: (Setiyawan \& Frieyadie, 2019)

The final result obtained from the calculation by the SAW method is the alternative that gets the most basic or feasible value in A15 that is as much as 1 debtor, and the feasible value with small risk is $\mathrm{A} 1, \mathrm{~A} 2, \mathrm{~A} 4, \mathrm{~A} 5, \mathrm{~A} 6, \mathrm{~A} 7, \mathrm{~A} 8, \mathrm{~A} 9, \mathrm{~A} 10, \mathrm{~A} 11, \mathrm{~A} 14$, A16, A17, A19, A21, A22 as many as 16, and the last value worthy of great risk is $\mathrm{A} 3, \mathrm{~A} 12, \mathrm{~A} 13$, A18, A20, A23 which is as many as 6. Decision making based on the results of the processing is carried out on the condition:

a. If Preference Value $<50$ Then the debtor is not eligible

b. If Preference Value $50 \&<70$ Then the debtor is Eligible with high-risk

c. If Preference Value $70 \&<90$ Then the debtor is Eligible with low risk

d. If Preference Value 90 - 100 Then the debtor is very feasible

From this table 13 to determine the feasibility parameters, the alternatives must be grouped according to their respective positions can be seen in table 14 , table 15 , and table 16 below:

Table 14 Debtors are very feasible

\begin{tabular}{cccccccc}
\hline $\begin{array}{c}\text { Alternative } \\
\text { (Debtor) }\end{array}$ & C1 & C2 & C3 & C4 & C5 & Total & Rank \\
\hline A15 & 35 & 12 & 25 & 12 & 8 & 92 & 1 \\
\hline Source: (Setiyawan \& Frieyadie, 2019) & &
\end{tabular}

Based on table 14, the debtor who is eligible to be given credit is 1 debtor, namely A15.

Table 15 Eligible with little risk

\begin{tabular}{cccccccc}
\hline Alternative & \multicolumn{7}{c}{ Criteria } \\
\cline { 2 - 8 } (Debtor) & C5 & C2 & C3 & C4 & C5 & Total & Rank \\
\hline A9 & 35 & 12 & 20 & 9 & 8 & 84 & 2 \\
A16 & 28 & 15 & 20 & 9 & 10 & 82 & 3 \\
A17 & 28 & 9 & 25 & 12 & 8 & 82 & 4 \\
A10 & 28 & 9 & 20 & 15 & 8 & 80 & 5 \\
\hline
\end{tabular}

P-ISSN: 1978-1946| E-ISSN: 2527-6514 | Implementation of the SAW ...

Rank 3 Accredited Journal based on Decree No. 21/E/KPT/2018

DOI: $10.33480 /$ pilar.v16i1.1302

\begin{tabular}{cccccccc}
\hline $\begin{array}{c}\text { Alternative } \\
\text { (Debtor) }\end{array}$ & \multicolumn{7}{c}{ Criteria } \\
\cline { 2 - 8 } & $\boldsymbol{C 5}$ & $\boldsymbol{C 2}$ & $\mathbf{C 3}$ & $\mathbf{C 4}$ & $\boldsymbol{C 5}$ & Total & Rank \\
\hline A11 & 28 & 9 & 25 & 12 & 6 & 80 & 6 \\
A1 & 28 & 15 & 20 & 9 & 6 & 78 & 7 \\
A14 & 28 & 9 & 20 & 15 & 6 & 78 & 8 \\
A19 & 28 & 15 & 15 & 12 & 8 & 78 & 9 \\
A5 & 28 & 12 & 20 & 9 & 8 & 77 & 10 \\
A8 & 28 & 9 & 25 & 9 & 6 & 77 & 11 \\
A21 & 28 & 12 & 15 & 12 & 8 & 75 & 12 \\
A4 & 28 & 9 & 20 & 9 & 8 & 74 & 13 \\
A6 & 28 & 12 & 15 & 9 & 10 & 74 & 14 \\
A2 & 28 & 12 & 10 & 15 & 8 & 73 & 15 \\
A7 & 21 & 12 & 20 & 12 & 8 & 73 & 16 \\
A22 & 21 & 9 & 20 & 15 & 6 & 71 & 17
\end{tabular}

Source: (Setiyawan \& Frieyadie, 2019)

Whereas based on table 15 above there are decent debtors with a small risk to be given a credit of 16 debtors.

Table 16 Eligible with great risk

\begin{tabular}{cccccccr}
\hline $\begin{array}{c}\text { Alternatif } \\
\text { (Debitur) }\end{array}$ & \multicolumn{7}{c}{ Kriteria } \\
\cline { 2 - 7 } & C1 & C2 & C3 & C4 & C5 & Total & Rangking \\
A3 & 21 & 12 & 15 & 12 & 6 & 66 & 18 \\
A13 & 21 & 12 & 15 & 12 & 6 & 66 & 19 \\
A23 & 28 & 9 & 15 & 6 & 8 & 66 & 20 \\
A18 & 21 & 9 & 15 & 12 & 6 & 63 & 21 \\
A20 & 14 & 9 & 20 & 9 & 10 & 62 & 22 \\
A12 & 14 & 9 & 15 & 9 & 8 & 55 & 23 \\
\hline
\end{tabular}

Source: (Setiyawan \& Frieyadie, 2019)

Based on table 16, there are 6 eligible debtors with high risk. For the percentage results obtained for granting credit to 23 debtors, can be seen in Figure 3 below.

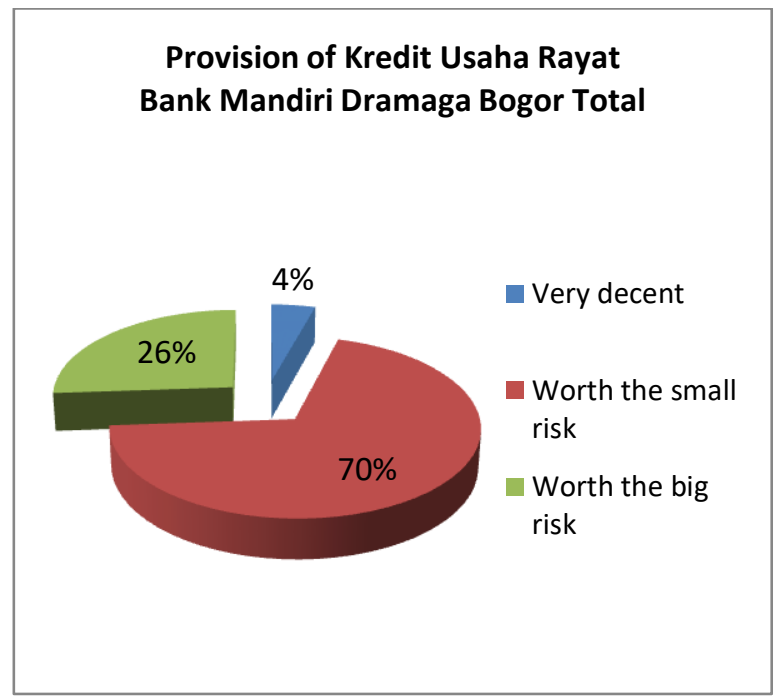

Source: (Setiyawan \& Frieyadie, 2019)

Figure 3 Provision of Kredit Usaha Rayat Bank Mandiri Dramaga Bogor Total

\section{CONCLUSION}

Based on the results of research conducted, it can be concluded that the decision 
support at Bank Mandiri Dramaga Bogor is expected to help give consideration in determining lending based on criteria determined by $5 \mathrm{C}$, namely Character, Capability, Capital, Collateral and Condition quickly and the output consists from appraisal evaluation. The results of calculations obtained by debtors who are very feasible given credit as much as 1 debtor (4\%), decent debtors with low risk as many as 16 debtors (70\%), and worthy of being given with high risk as many as 6 debtors (26\%). Decision Supporters who can avoid bad credit and can reduce mistakes made by human error in processing data and improve the performance and process of getting debtors.

\section{REFERENCE}

Bank Mandiri. (2019). Data of Bank Mandiri KUR Debtor Candidates for Dramaga Branch in the January - March 2019 Period.

Hasugian, H., Mursyidin, I. H., \& Handayani, M. D. (2018). SISTEM PENUNJANG KEPUTUSAN PEMBERIAN KREDIT DENGAN METODE SIMPLE ADDITIVE WEIGHTING (SAW) STUDI KASUS: KOPERASI KARYAWAN GATERA PT PLN (PERSERO) AREA KEBAYORAN. SINTAK, 465-471.

https://www.unisbank.ac.id/ojs/index.php/ sintak/article/view/6657

Hermawan, A., \& Evan. (2019). The Hotel Recommendation System Using SAW (Simple Additive Weighting) And TOPSIS (The Technique for Order of Preference by Similarity to Ideal Solution) Method. Bit-Tech, 1(3), https://doi.org/10.32877/bt.v1i3.71

Kanuru, L. B., Sihotang, D. M., Djahi, B. S., Komputer, J. I., Cendana, U. N., \& Keputusan, S. P. (2018). SISTEM PENDUKUNG KEPUTUSAN PEMBERIAN PINJAMAN MENGGUNAKAN APLIKASI FUZZY SIMPLE ADDITIVE WEIGHTING ( STUDI KASUS : KOPERASI KREDIT MONAFEN ). 6(1), 28-36.

M. Chandra C. Utomo, Wayan Firdaus Mahmudy, S. A. (2014). Sistem Pendukung Keputusan Kelayakan Pemberian Kredit Motor Menggunakan Metode Simple Additive Weighting pada Perusahaan Leasing HD Finance. Jurnal SPK Kelayakan Pemberian Kredit Motor, 1-9.

Mulyati, E., \& Dwiputri, F. A. (2018). PRINSIP KEHATI-HATIAN DALAM MENGANALISIS
JAMINAN KEBENDAAN SEBAGAI PENGAMAN PERJANJIAN KREDIT PERBANKAN. Acta Diurnal Jurnal Ilmu Hukum Kenotariatan Dan Ke-PPAT-An, 1(2), 134. https://doi.org/10.24198/acta.v1i2.112

Purnama, I. P. N., Fid Aksara, L. M., Statiswaty, Saputra, R. A., \& Ramadhan, R. (2019). Decision suport system to increase salary of bank sultra's teller employee with performance assessment parameters using fuzzy Tahani method and simple adaptive weighting. ACM International Conference Proceeding Series, 210-215. https://doi.org/10.1145/3330482.3330488

R. Febrianti, S., Hidayat, N., \& Suprapto. (2018). Sistem Pendukung Keputusan Rekomendasi Pemberian Usaha Kredit Mikro (UKM) dengan Metode AHP-SAW (Study Kasus: PD. BPR Bojonegoro). Jurnal Pengembangan Teknologi Informasi Dan Ilmu Komputer (JPTIIK) Universitas Brawijaya, 2(8), 26202627.

Riyandi, A. O., Dengen, N., \& Islamiyah. (2017). Sistem Pendukung Keputusan Kelayakan Pemberian Bantuan Dana atau Kredit Untuk Usaha Kecil Menengah (UKM) pada Bank Negara Indonesia (BNI). Prosiding SAKTI (Seminar Ilmu Komputer Dan Teknologi Informasi), 2(1), 8-13.

Setiyawan, R., \& Frieyadie, F. (2019). Final Report of the Independent Research: Implementation Of The Saw Method As A Decision Support For Giving Feasibility of KUR On Bank Mandiri Dramaga Bogor.

Sibyan, H. (2018). PENILAIAN KELAYAKAN KREDIT PADA KPRI EDIPENI KEPIL WONOSOBO DENGAN METODE SIMPLE ADDITIVE WEIGHTING (SAW). Jurnal Penelitian Dan Pengabdian Kepada Masyarakat UNSIQ, 5(2), 198-205. https://doi.org/10.32699/ppkm.v5i2.464

Siyoto, S., \& Sodik, M. A. (2015). Dasar Metodologi Penelitian. Literasi Media Publishing.

Sudiarjo, A., \& Ruuhwan, R. (2020). Application of the Simple Additive Weigthing Method in the selection of housing in the city of Tasikmalaya. Journal of Physics: Conference Series, 1477(1), 1-6. https://doi.org/10.1088/1742$6596 / 1477 / 3 / 032025$ 
Utomo, Y. B., \& Ipmawati, J. (2016). Sistem Pendukung Keputusan Penentuan Penerima Kredit Usaha (Studi Kasus: Adira Finance Kediri) | Utomo | Creative Information Technology Journal. Creative Information Technology Journal, 3(4), 295-306. https://ojs.amikom.ac.id/index.php/citec/ar ticle/view/1943

Waspodo, B., Qoyim, I., \& others. (2014). Sistem Pendukung Keputusan Pemberian Kredit Usaha Akad Musyarakah dengan Metode SAW (Studi Kasus: BPRS Al-Barokah). Konferensi Sistem Informasi Indonesia, 27-32.

Yasdomi, K., \& Chandra, D. A. (2017). Sistem Pendukung Keputusan Pemberian Kredit Menggunakan Metode Simple Additive Weighting (SAW) (Studi Kasus Koperasi Bengkawas Jaya). Riau Journal of Compute Science, 3(1), 41-48. http://ejournal.upp.ac.id/index.php/RJOCS/article/v iew/1172

Zein, H. (2014). APLIKASI SISTEM PENDUKUNG KEPUTUSAN PEMBERIAN KREDIT USAHA RAKYAT MENGGUNAKAN METODE SIMPLE ADDITIVE WEIGHTING ( SAW ) (Studi kasus
Pada Bank Syariah Mandiri Cabang Medan). Pelita Informatika Budi Darma, vi, 164-167. 